\title{
Corrosion Monitoring of RC Structures (Assessment and Interpretation)
}

\author{
Bharat Kr. Suthar
}

\begin{abstract}
Reinforced Concrete structure system is more durable and capable from a various adverse environmental condition. Their excellent tensile strength and ductility make them perfect for construction of building structures. Structures are always susceptible to environmental changes. No building will ever be the same once the environmental changes kick in. Out of all the changes, the most serious and devastating in corrosion. Each and every structure needs valuable inspection and proper examination for checking the reinforcement corrosion. There are required assessing and techniques to evaluate and interprets the condition of structures. One can identify the strength of a structure by monitoring techniques and can prevent problem in the structures before it becomes crucial. In this review paper all the non destructive techniques from the point of view of corrosion assessment and application to building and other civil engineering structures are being discussed.
\end{abstract}

Keywords : Corrosion, Monitoring Application, electro chemical methods.

\section{INTRODUCTION}

Corrosion of reinforcement can be defined as an electrochemical reaction which completes in various stages. Initial reaction starts occurring at the anodic areas of the surface and the electrons are released from the anode and they travel through the RC structure to the cathode sites, when they combine with $\mathrm{O}_{2}$ and water then corrosion start. In RCC structures the most important causes of corrosion in reinforcement is carbonation and chloride attack. After initiation of corrosion the corrosion product $\left(\mathrm{Fe}_{2} \mathrm{O}_{3} \& \mathrm{OH}^{-}\right)$ are usually deposited in the restricted space in the concrete around the steel. Their occurrence within this confined space causes the Compressive stresses, which distress the concrete cover. This is result in deterioration of concrete. For evaluation and measurement of corrosion possibility and corrosion rate there structure need monitoring techniques which detect it. There are many structures which show distress and cracks in very short period of time usually the state of structures can be examined by the observing it visually. Heavy corrosion is a serious problem in RCC Structures which can be detected by some other alternative method. One can examine the condition of structures by multiple corrosion survey and maintaining information. For measuring the rate of corrosion we prefer NDT method. RC Corrosion of existing Structures can be measured by different method such as :
1. Half-cell Potential Measurement Method

2. Resistivity Test

3. Test for carbonation of concrete

4. Test for chloride content of concrete

5. Endoscopy Technique

6. Profometer

\section{HALF-CELL POTENTIAL MEASUREMENT METHOD}

This is a instrument which is used for the collection of huge amount of data from the surface of the structures. It is the most commonly used electrochemical process to detect the risk of corrosion in RCC Structures.

As per Half-Cell potential tests, assessing the probability/risk of corrosion in the structural member: - Uncertain Risk. Permeability of concrete has an inverse relationship with the concrete cover depth and is directly related to the corrosion of the reinforcement steel. Steel are sufferings from $50 \%$ active corrosion risk except in the structure. There is $50 \%$ probability of corrosion in reinforcement where corrosion has not yet started. Wherever corrosion is visible RCC sections are exposed and already spalling of concrete is visible. The corrosion potential survey is used to give the probability of corrosion activity of reinforcing steel in the concrete at the time of the survey. In this procedure, a reference electric current is connected to a voltmeter and also connected to the reinforcing steel. The difference in voltage between

The reinforcing steel and the current source can be correlated to the amount of corrosion. According to ASTM C 876 [6] standards, the possibility of RC Corrosion is shown in the table below. The difference in voltage between the reinforcing steel and the current source can be correlated to the amount of corrosion.

Table I: Corrosion Possibility according to measurement

\begin{tabular}{|l|l|}
\hline Potential & $\begin{array}{l}\text { Corrosion of } \\
\text { Probability }\end{array}$ \\
\hline More negative than $-350 \mathrm{mV}$ & $>95 \%$ \\
\hline-200 to $-350 \mathrm{mV}$ & $50 \%$ \\
\hline More positive than $-200 \mathrm{mV}$ & $<5 \%$ \\
\hline
\end{tabular}




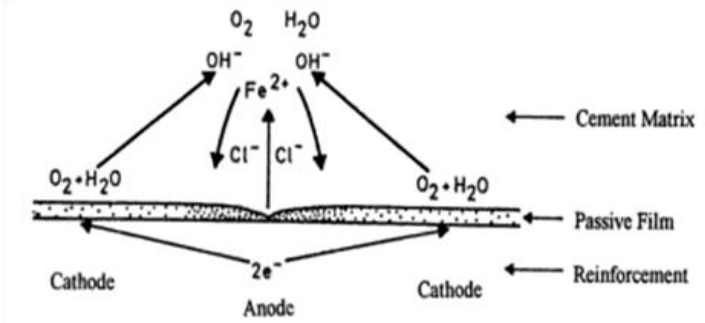

Fig 1 Corrosion Mechanism of Reinforcement

III. IT.

Influencing factor:

Concrete cover thickness: More positive potential as the more concrete cover thickness increases and more electrical resistivity (RILEM TC 154-EMC 5.2.3)

Oxygen concentration and $\mathbf{P H}$ at the steel surface: with decreasing oxygen concentration and increasing $\mathrm{PH}$ at the steel surface its potential become more negative (RILEM TC 154-EMC 5.2.3)

Presence of Contamination on Concrete: On increasing the content of chloride the electrical resistivity of concrete decrease and corrosion increases. (as per ASTM C 876-91 clause9.4,CANIN PROVISTA,RILEM TC 154-EMC 5.2.2)

Saturated surface: More (-)ve potential.

Effect of water content and concrete porosity: water content and porosity of concrete are directly proportion to the electrical resistivity of concrete cover ;( RILEM TC 154-EMC 5.2.2)

\section{RESISTIVITY TEST}

Surface resistivity test tells about the condition of concrete structures. Its note only linked with corrosion rate, it's also linked with chloride dispersal duty. This method is used to determine following aspects:

$$
\begin{array}{ll}
\circ & \text { Prediction of corrosion. } \\
\circ & \text { Observation of corrosion quantity. } \\
\circ & \text { Interpretation to chloride diffusion rate. } \\
\circ & \begin{array}{l}
\text { Determination of requirements for cationic } \\
\text { preventing systems }
\end{array} \\
& \text { Finding of areas within a RC Structures most } \\
& \text { susceptible to chloride penetration }
\end{array}
$$

Two inner \& two outer probes were used in this method and a current is passed through the pore fluids or liquids and potential difference was evaluated between them. The current is carried by ions in the pore fluid or liquid. The distance between the probes is also directly proportional to the resistivity.

$$
\rho=2 \pi \mathrm{A} V / \mathrm{I} \quad(\text { Resistivity) Unit: } \mathrm{k} \Omega \mathrm{cm}
$$

\section{Influence factor}

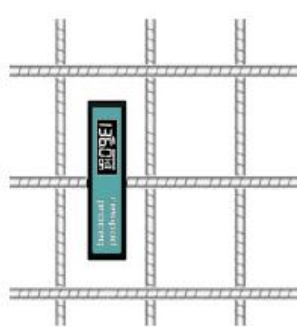

Fig 2

a. Due to the presence of steel in concrete structures the current passes in large quantity as compare to concrete structure without steel. This effect occurs only when the cover depth is less than $30 \mathrm{~mm}$. Use a rebar locator to determine the rebar location and cover depth

b. .Reinforcement bars should not be present under the probes as well as should not be running parallel to the probes .it will be more preferable to measure diagonally to the reinforcement as shown in the fig . It is only possible when the space between rebar is very less.

c. If the space between the rebar is so close that it cannot be avoided, to avoid any type of error in reading we should measure perpendicular to the rebar as shown in fig.

d. The concrete surface should not be electrically insulated. It should be clean. By the help of rebar locator we can mark out the rebar grid beneath the structures.

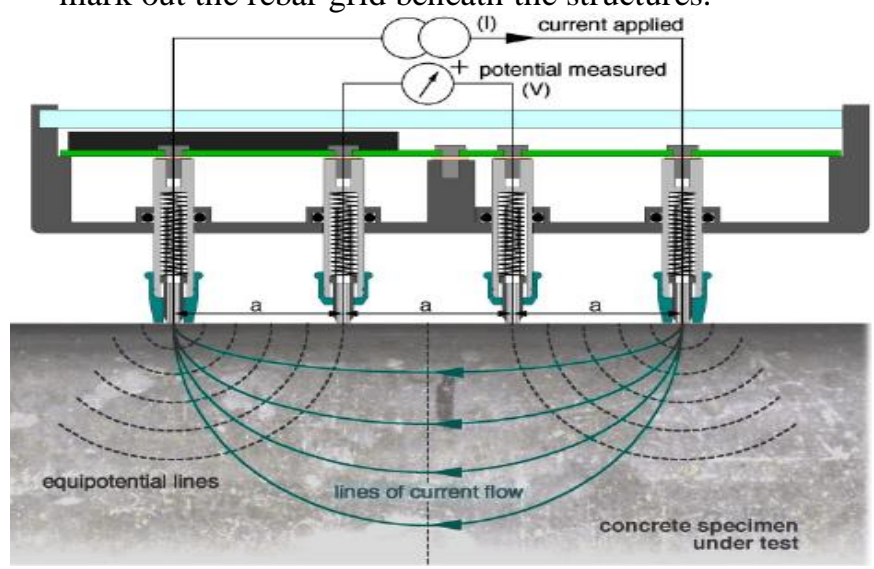

Fig 3 Half cell potential meter

Resistivity is measured in $\mathbf{k} \mathbf{\Omega} \mathbf{c m}$ and correspondence to its there is codal criteria (BS EN 12696:2000, RILEM TC-154, AASHTO T277 RCP, AASHTO T259) related to chance of corrosion.

Table II: Corrosion Possibility according to resistivity

\begin{tabular}{|l|l|l|}
\hline $\begin{array}{l}\text { Resistivity in } \\
\text { Ohm-cm } \mathbf{( \Omega c m})\end{array}$ & $\begin{array}{l}\text { Resistivity in kilo } \\
\text { Ohm-cm }(\mathbf{k} \mathbf{c m})\end{array}$ & $\begin{array}{l}\text { Corrosion } \\
\text { Probability }\end{array}$ \\
\hline$>20000$ & $>20$ & Negligible \\
\hline $10000-20000$ & $10-20$ & Low \\
\hline $5000-10000$ & $5-10$ & High \\
\hline$<5000$ & $<5$ & Very High \\
\hline
\end{tabular}

\section{TEST FOR CARBONATION OF CONCRETE}

The carbonation depth gives an idea about the deterioration of the concrete and further gives an idea about the corrosion of the steel and bonding nature of the structural compound. The carbonation test generally carried out in-situ on a piece of concrete. 
It may be done in laboratory on test specimen core or fragment remove from the structure. The concrete surface is sprayed with the indicator such as solution of phenolphthalein. The surface should could transport dissolved alkalise and obscure the location of the carbonation front. Where the concrete loss their alkalinity, phontphthelin

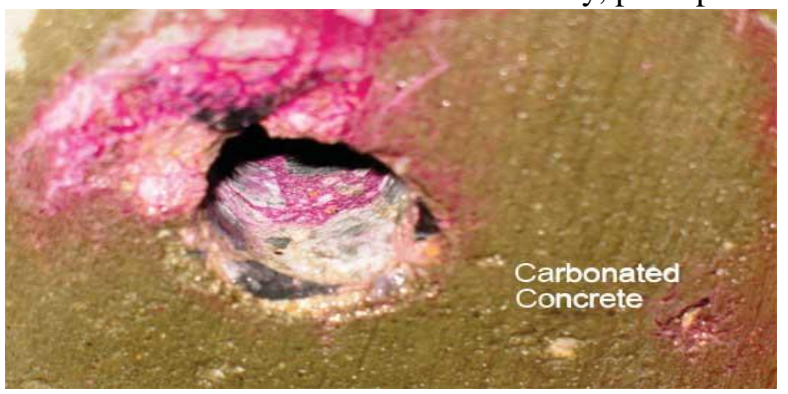

Fig.3 Carbonated Concrete

Aspects of carbonation test.

- The depth should be measured from which an instantaneous colour change to pink within 30 second. If the change is slow and or boundary is diffuse. it may be indicate partial carbonation /

- If the concrete surface is dry then a light mist of water is applied before phenolphthalein solution applied.

- Drill or cut surface may give misleading result.

- Concrete that has been realkalised by diffusion or by electrochemical means may show high PH. The PH around the reinforcement may a high enough for the phenolphthalein to temporarily remain colourless. This effect wears off after a few hours. It should be noted that although the $\mathrm{PH}$ may be characteristic of uncarbonated concrete. The realkalisation process does not reverse the carbonation reaction.

\section{Carbonation Depth:}

It is measure from the external surface of the concrete to the edge of the coloured region. In this test average and maximum $\left(d_{k}\right.$ or $d_{k, \max }$ depth should be measured

Whole Protective layer is not carbonated yet (Maximum carbonation depth $4 \mathrm{~mm}$ ) and in present case carbonation depth is lower than depth of cover so structure is in incubation period (not in deterioration period). If depth of carbonation is greater than cover depth, then incubation period is over; degradation rate will be accelerated. (B.S 4248).

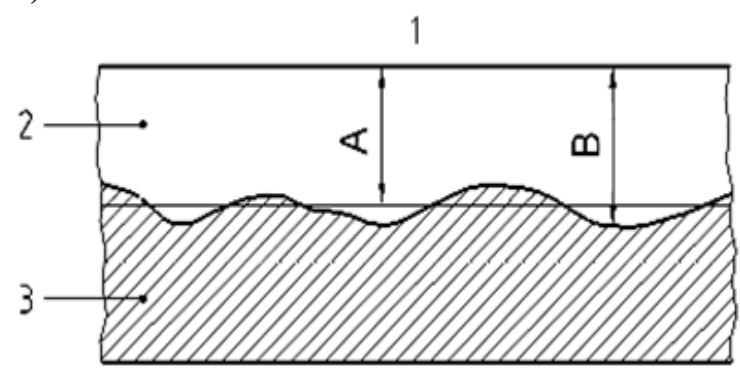

shows the pink color when the concrete surface become alkaline otherwise remain colorless. The indication of partial carbonation can be determine by the identifying the rate of change of speed of indicator. The high alumina cement cannot test by this method.
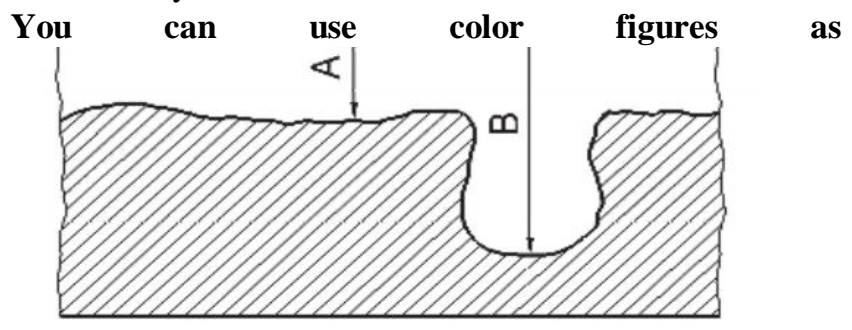

$\mathrm{A}=\mathrm{d}_{\mathrm{k}, \mathrm{B}}=\mathrm{d}_{\mathrm{k}, \max }$

Fig.4 Isolated pocket of deeper section

\section{Influence factor}

Type of cement:- pozzolanic cements, and especially the NPC and the AHPC, have a lower $\mathrm{Ca}(\mathrm{OH})_{2}$ content than OPC. Because pozzolanic material content $\mathrm{CaO}$ in lower amount than the production of $\mathrm{Ca}(\mathrm{OH})_{2}$ in lower amount this cause the rate of carbonation decrease

Environment condition:-when structure subjected to highly toxic gases $(\mathrm{CO} 2, \mathrm{CO})$ than the carbonation process increase due to increase in concentration of $\mathrm{CO}_{2}$ gases.

Permeability:- the presence of carbonation in concrete voids is inversely proportional to the permeability of concrete structures. This problem can be seen in old structures. Because after reaction of $\mathrm{CO}_{2}$ with $\mathrm{Ca}(\mathrm{OH})_{2}$. The precipitation of $\mathrm{Caco}_{3}$ occur which fill the all voids of concrete.

Relative humidity:-effect of relative humidity on carbonation depth. Similarly the rate of carbonation and thus carbonation depth goes through a maximum at relative humidities around 55 percent. When Relative humidity of atmosphere is $50 \%-70 \%$ then carbonation process increase. Because relative humidity below $25 \%$ is insignificant and when humidity above $75 \%$ then this fill the all voids of concrete so this cause the penetration of $\mathrm{CO}_{2}$ prevent. Then process of carbonation decrease..

Water cement ratio:-when $\mathrm{CO} 2$ gets dissolved in small concentration into poor quality concrete with high water ratio. It reacts with $\mathrm{Ca}(\mathrm{OH}) 2$ and gives out $\mathrm{CaCO} 3$. Deterioration of concrete mainly depends on the carbonation effect is not a serious problem provided that concrete is properly proportioned has low w/c ratio and is properly consolidated and adequate cured.

PH Value The pore fluid when get attacked by carbonation its alkalinity get reduced and the $\mathrm{pH}$ value reached to 8-9 range. When the carbonation happens in the front then the $\mathrm{pH}$ value is above 10.5 . When carbonation diffuses onto the concrete surface then the $\mathrm{pH}$ level drops down and passive layer surrounding the reinforcements gets damaged and the corrosion of reinforcements starts.

\section{TEST FOR CHLORIDE CONTENT OF CONCRETE}

The protective layer (i.e. passivity) can be damaged by the attack of chloride ions on to the concrete. Generally metal

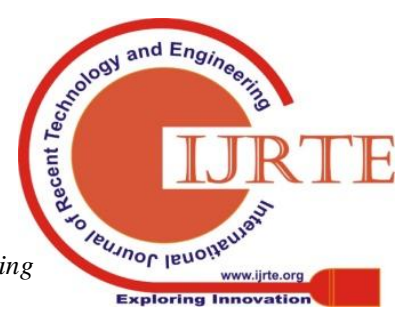


protect by the alkalinity. But by the presence of chloride de-passivity the metal and occur active metal dissolution. In chemical process chloride reacts with the calcium aluminates or alumina ferrite in structure to form chloro aluminates or calcium chloroferrites. And this solution that is promotes the corrosion in reinforcement. For the assessment of chloride content in concrete structure

One should take the core by using core cutter equipments Slice them in no. of disc about 10 to $25 \mathrm{~mm}$ thickness. Chloride content in concrete can be determine at laboratory as per (BS 1881; 124) by using indicator such as silver nitrate and potassium chromate.

If $\mathrm{C1} \%$ by weight of concrete v/s of corrosion. up to $0.05 \%$ - low risk; 0.05 to $0.15 \%$ - medium risk; above $0.15 \%$ - high risk

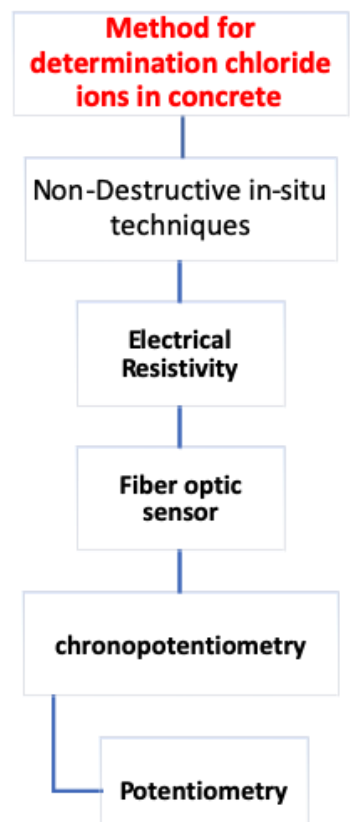

Table III

American concrete institute recommends the following limit for chloride in new construction (ACI-222R-01)

\section{ENDOSCOPY TECHNIQUE}

Endoscopy is a very powerful technique to detecting void and corrosion in reinforcement. There are attachment of camera and monitor to visualize the detecting parts. There are requirement of experienced engineer to operate it. Firstly hole drill into concrete component then insert a flexible or rigid tube into it. And view them with optical light provided into hole. Viewing a result on monitor.

\section{PROFOMETER}

In $\mathrm{RCC} / \mathrm{PCC}$, adequate cover thickness is important to prevent corrosion of the steel. Profometer is instrument which is used to detect the location of steel bar and cover thickness by using the principle of eddy current. It generates pulse to gather the data. It uses magnetic field to locate steel bar and tells about its cover depth and diameter of bar. Its objective is to determine cover depth and correlate between protective layers or cover depth to penetration depth of deterious agent.

This instrument is also known as rebar locator. It is a simple but sophisticated device. Its shows information on its LCD

Display. It has enough amount of memory to keep a record of measured data.

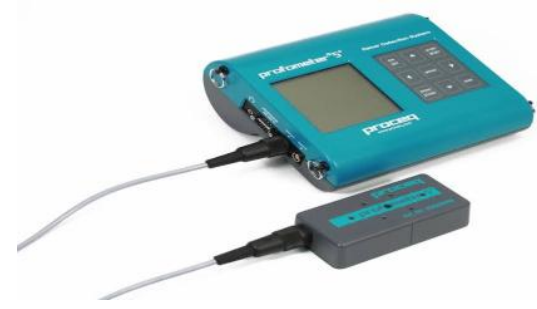

Various Interpretation Mechanism

1. Correlation Between Chloride

Content/Carbonation/Cover Depth:

Depth of cover is measured to correlate the carbonation depth in concrete as well as susceptibility to penetrate the chloride ions into concrete Carbonation proceeds from the surface into concrete. Carbonation destroys passive protection provided by concrete to the reinforcement. When depth of carbonation reach concrete cover reinforcement corrosion is occur. In present condition of building the depth of carbonation is lower than cover depth so there is passivity of carbonation attack on R.C.C

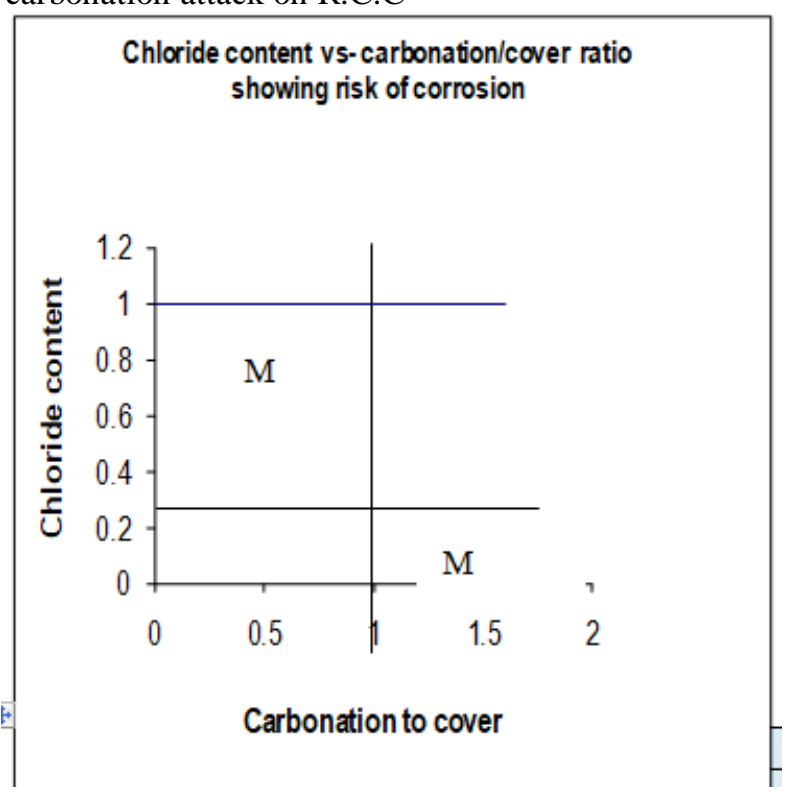

\begin{tabular}{|c|c|c|c|}
\hline \multirow[b]{4}{*}{ Category } & \multicolumn{3}{|c|}{ Chloride limit for new } \\
\hline & \multicolumn{3}{|c|}{$\%$ by mass of cement } \\
\hline & $\begin{array}{l}\text { Acid } \\
\text { Soluble } \\
\end{array}$ & Water & Soluble \\
\hline & $\begin{array}{l}\text { ASTM } \\
\text { C } 1152\end{array}$ & $\begin{array}{l}\text { ASTM } \\
\text { C } 1218\end{array}$ & Soxhlet \\
\hline $\begin{array}{l}\text { Prestresse } \\
\text { d Concrete }\end{array}$ & 0.08 & 0.06 & 0.06 \\
\hline
\end{tabular}

Published By: 


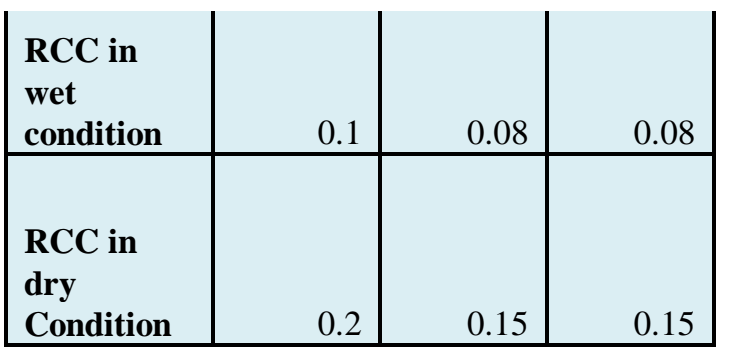

$M^{* *}=$ Moderate

A). When chloride content in concrete lower than 0.4 \& carbonation to cover up to 1 than the risk of corrosion is low.

B). When chloride content in concrete less than 0.4 and carbonation to cover more than 1 than risk of corrosion moderate.

C). When chloride content in concrete more than 0.4 and carbonation to cover less than 1 then risk of corrosion moderate.

D). When chloride content in concrete more than 0.4 and carbonation to cover more than 1 than risk of corrosion high.

\section{Relation Between Corrosion Rate And \% Of}

Chloride Content :- (Aci)

- Corrosion rate of steel rods embedded in concrete increase with an increase in admixed chloride content. the chloride content threshold limit appeared to between 0.2 to 0.4 percent calcium chloride dehydrate by weight of cement

- The chloride in chloride aggregate used for this investigation was not available for any significance degree for the corrosion process.

- The electrical resistivity of concrete containing admixture chloride decrease with increase chloride content.

- The PH of concrete varies between 12 to 12.5 regardless of admixed chloride content and type of aggregate used in mixes.

- If the cement provide highly alkaline environment only then it will be able to protect the reinforcement steel by forming a protective layer around the steel. When the chloride content is equal and greater than $0.2 \%$ by the weight of cement or $0.03 \%$ by the weight of the concrete, the protective layer will be damaged, and corrosion will start. If the enough amount of oxygen or moisture content present in structures.

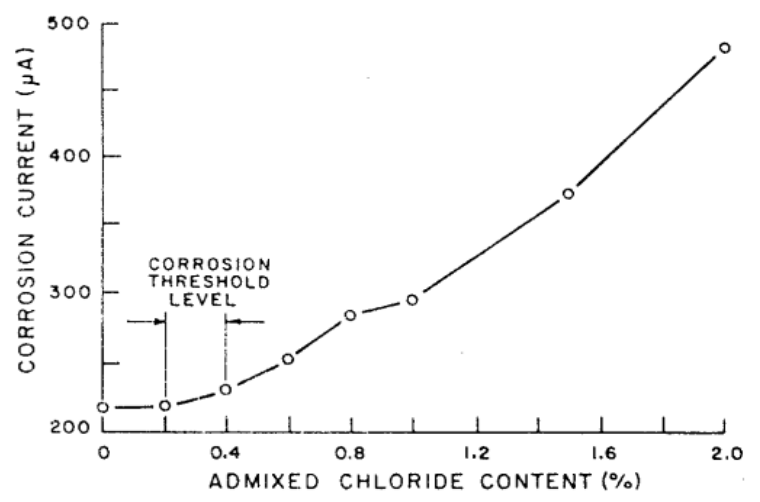

Fig 5 Relation between corrosion and chloride

\section{Relation Between Concrete Depths,}

\section{Carbonation And Ph Value :- (Ip6/81)}

Carbonation itself doesn't cause the deterioration in reinforcement concrete. But it changes the $\mathrm{PH}$ value of liquid solution present in pore of concrete. Carbonation is a progressive reaction beginning at surface of concrete and penetrate deeper and deeper with respect to time due to diffusion of carbon dioxide into the concrete.

Researcher afterward defined the carbonation, semi carbonation, non-carbonation zone. Corresponding to $\mathrm{PH}$ value of concrete.

Non-carbonation zone have PH above the 12.6. Where totally carbonated concrete have $\mathrm{PH}$ value about 8.3.

The semi-carbonation $\mathrm{PH}$ value increase with the depth of concrete varies from 8.3 to 12.6 . Which show in fig.

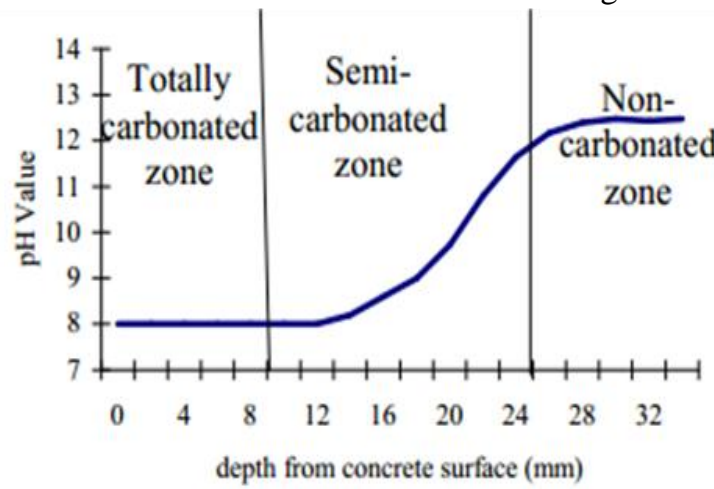

Fig.6 PH Value profile of carbonation concrete

\section{1) Relation Between Carbonation Depth And Compressive Strength Of Concrete Pp.14-20(2002)}

Carbonation of concrete due to $\mathrm{CaCO} 3$ content is more than $\mathrm{Ca}(\mathrm{OH}) 2$ in concrete structure., reduction in surface pore is due to $\mathrm{CaCO} 3$. Then relationship between carbonated depth and strength of concrete is shown in fig.7 .Strength of concrete decrease with increase of carbonation depth. In which compressive strength of concrete with $100 \% \mathrm{CO} 2$ concentration at the age of 28 days is shown.

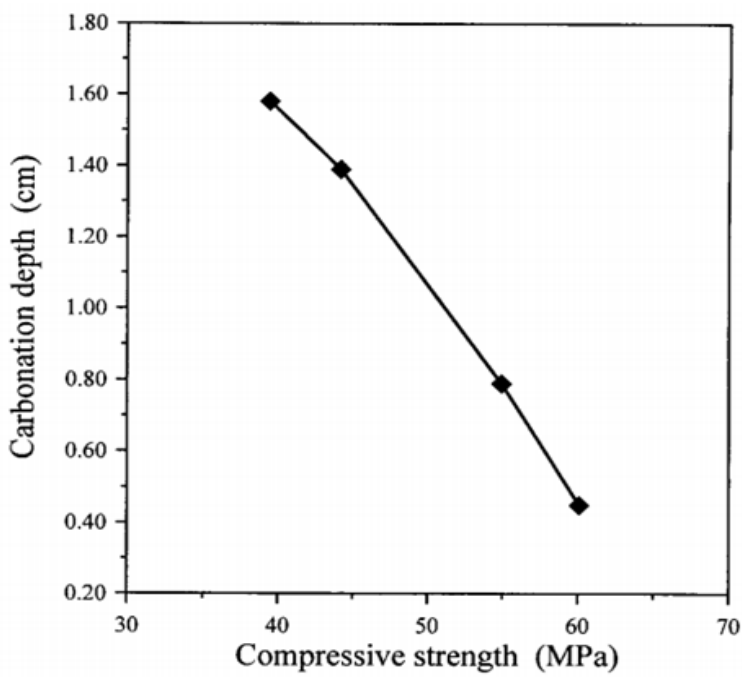

Fig 7 relation between carbonation depth and compressive strength

Published By: 


\section{CONCLUSION}

In this review paper all the non destructive techniques from the point of view of corrosion assessment and application to building and other civil engineering structures are being discussed.

\section{REFERENCES}

1. American Society for Testing and Materials "Corrosion Possibility according to measurement" ASTM C 876 [6] standards,

2. Reunion international laboratories and experts in construction materials "Introduction about half cell potential measurement (RILEM TC 154-EMC 5.2.3),

3. American Society for Testing and Materials "presence of contamination of concrete"ASTM C 876-91 clause9.4,

4. CANIN PROVISTA "presence of contamination of concrete" ,RILEM TC 154-EMC 5.2.2),

5. the British adoption of a European (EN) standard "Resistivity measures"(BS EN 12696:2000,

6. Reunion international laboratories and experts in construction materials "resistivity measures"RILEM TC-154,

7. The American Association of State Highway and Transportation Officials „chancxes of corrosion“AASHTO T277 RCP,

8. Ervin Poulsen."Chloride Profiles" AEClaboratory, 20 staktoften. DK-2850 Vedback, denmark.

9. Peter A Claisse, "Carbonated Concrete" Hanaa I Elsayad and Ibrahim G Shaaban.

10. Ralf ARNDT1, Frank JALINOOS "Corrosion assessment and monitoring" Federal Highway Administration, TFHRC NDE Center, McLean, United States.

11. AI Abu-Tair1 C McParland2 JF Lyness2 A Nadjai "deterioration of concrete structures." Faculty of Engineering Al-Quds University Jerusalem

2 School of the Built Environment University of Ulster N Ireland

12. Zenonas Kamitis "Reinforcement Corrosion" Dept. of Bridges and special structures, Vilnius Gediminas Technical University,Sauletekio.11 LT-2040 VILNIUS, Lithuania

13. The American Association of State Highway and Transportation Officials(AASHTO T259) "Corrosion Possibility according to Resistivity",

14. British standards "Corrosion Possibility according to Resistivity" (BS $1881 ; 124)$,

15. American concrete institute "chloride limit of concrete and RCC Structures(ACI-222R-01)

\section{AUTHORS PROFILE}

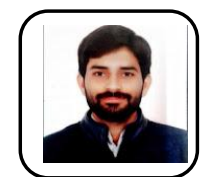

Bharat Kr. Suthar, Lecturer, Department of civil engineering, Techno India NJR Institute of Technology, Udaipur(India) . 